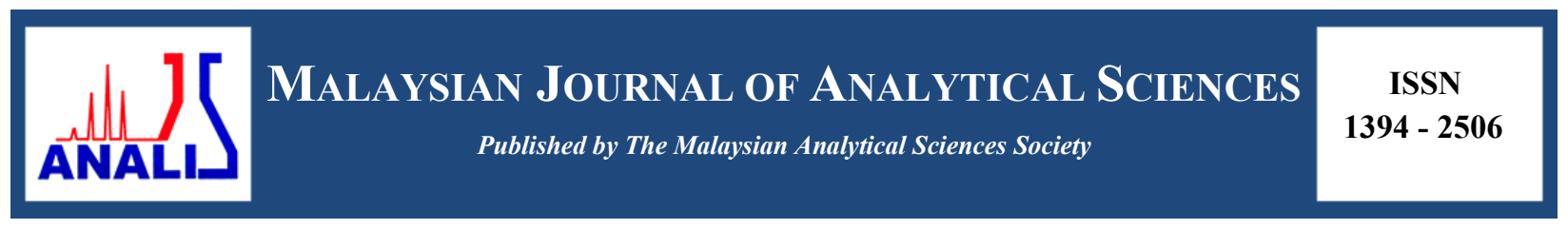

\title{
SYNTHESIS OF MESOPOROUS SODALITE BY MIXED QUATERNARY AMMONIUM CATION TEMPLATES FOR KNOEVENAGEL CONDENSATION REACTION
}

\section{(Sintesis Sodalit Mesoliang dengan Campuran Templat-Templat Kation Amonium Kuaterner untuk Tindak Balas Kondensasi Knoevenagel)}

\author{
Mohamad Faiz Othman, Shima Shirani Lapari, Zainab Ramli*, Sugeng Triwahyono \\ Department of Chemistry, Faculty of Science, \\ Universiti Teknologi Malaysia, 81310 UTM Johor Bahru, Johor, Malaysia \\ *Corresponding author: zainabr@utm.my
}

Received: 20 September 2016; Accepted: 16 May 2017

\begin{abstract}
Sodalite (SOD) is a microporous zeolite with pore size about $2.8 \AA$ which limits its role as catalyst for the reaction involving bulky molecules. To overcome this disadvantage, mesotemplate can be added to create mesoporosity in the synthesis of SOD. A series of SOD samples was synthesized using dual templates approach by mixing tetrapropylammonium hydroxide (TPAOH) with different quaternary ammonium cations. The samples were characterized using X-ray Diffraction (XRD), Fourier Transformation Infrared (FTIR) and $\mathrm{N}_{2}$ adsorption analysis. From $\mathrm{N}_{2}$ adsorption analysis, only SOD sample prepared by mixing TPAOH with organosilane (SOD-TO) showed the characteristic of mesoporosity with a narrow pore size distribution peak centered at ca. $66 \AA$. The basicity properties of all SOD samples were evaluated by Hammett indicators test and back titration method. While, the basicity property of SOD-TO was compared with the microporous SOD (Na-SOD) using TPD-CO ${ }_{2}$ analysis. All SOD samples were tested in the Knoevenagel condensation reaction of benzaldehyde and diethyl malonate, giving diethyl-2benzylidenemalonate as the main product. The results showed that SOD-TO catalyst which possessing the highest amount of basicity and the highest surface area with mesoporosity character gave the highest percentages of conversion and yield of Knoevenagel reaction.
\end{abstract}

Keywords: sodalite, basic catalyst, dual templates approach, mesoporous sodalite, Knoevenagel condensation reaction

\begin{abstract}
Abstrak
Sodalit (SOD) ialah zeolit mikroliang dengan liang bersaiz sekitar $2.8 \AA$ yang menghadkan peranannya sebagai mangkin untuk tindak balas yang melibatkan molekul - molekul yang besar. Untuk mengatasi kekangan ini, mesotemplat boleh ditambahkan dalam sintesis SOD bagi mengwujudkan mesoliang dalam SOD. Satu siri SOD telah disintesis menggunakan pendekatan dwi templat dengan campuran tetrapropilamonium hidroksida (TPA) dengan pelbagai kation amonium kuaterner. Semua sampel telah dicirikan menggunakan pembelauan sinar-X (XRD), Inframerah Tranformasi Fourier (FTIR) dan analisis penjerapan $\mathrm{N}_{2}$. Daripada analisis penjerapan $\mathrm{N}_{2}$, sampel SOD yang disintesis hasil campuran TPA dengan organosilana (SOD-TO) sahaja yang menunjukkan ciri-ciri mesoliang dengan puncak penyebaran sempit saiz liang berpusat di ca. $66 \AA$. Ciri-ciri kebesan untuk semua sampel SOD telah dinilai menggunakan ujian petunjuk Hammett dan kaedah titratan berbalik. Manakala, ciri-ciri kebesan SOD-TO telah dibandingkan dengan SOD mikroliang (Na-SOD) menggunakan analisis TPD-CO 2 . Semua sampel SOD telah diuji dalam tindak balas kondensasi Knoevenagel antara benzaldehid dan dietil malonat yang menghasilkan dietil-2benzilidenemalonat sebagai hasil utama. Keputusan menunjukkan mangkin SOD-TO yang mempunyai jumlah kebesan dan luas permukaan yang paling tinggi dengan kehadiran ciri mesoliang dalam strukturnya memberikan peratusan penukaran dan hasil yang paling tinggi bagi tindak balas Knoevenagel.
\end{abstract}


Kata kunci: sodalit, mangkin bes, pendekatan dwi templat, sodalit mesoliang dan tindak balas kondensasi Knoevenagel

\section{Introduction}

Zeolites are microporous crystalline aluminosilicate solids made up from corner-sharing of $\mathrm{SiO}_{4}^{-}$and $\mathrm{AlO}_{4}^{-}$ tetrahedra. These tetrahedra are linked together by sharing all the oxygen atoms, forming a uniformly pores or channels of molecular dimensions [1]. Microporous zeolites are widely used as catalysts in organic catalytic reactions due to their excellent catalytic performance such as large surface area, environment friendly, easy work-up and shape-selectivity [2]. However, in reactions involving large molecules, the sole presence of micropores in zeolites limit the diffusion of large molecules and lead to poor catalytic performance [3]. Therefore, many studies have been focusing on synthesizing zeolites with proper pore size in order to accelerate the conversion of large molecules. One of the best strategies is by synthesizing a new zeolite that consists of micropores and mesopores $(2-50 \mathrm{~nm})$ in one material. This strategy leads to the formation of hierarchical porous zeolites or also known as mesoporous zeolites [4]. Mesoporous zeolites offer some advantages such as fast diffusion and accessible for large molecules [5].

There are many methods to introduce mesopores in the zeolite structure. The most common methods used are postsynthetic method and templating method [6]. Desilication and dealumination are examples of post-synthetic method. This method has some drawbacks such as reducing the number of active sites and non-uniform nature of the mesopore formation [7]. Recently, the synthesis of mesoporous zeolites has been done by templating methods. This can be achieved by introducing various templates such as "hard" or "soft" templates into the zeolites during the synthesis process. This low cost method allowed reducing in the number of synthetic steps during the preparation [8]. Among these two templates, soft templating approach has been widely used for synthesizing mesoporous zeolites. Some examples of soft templates are surfactants and polymers [9]. The major advantage by using soft templates is the easily removed of the templates by a calcination process [10]. Instead of using single soft template, the mesopore zeolites can also be synthesized by mixing two soft templates. This strategy is known as dual templates method by which the small molecular template is used as structure directing agent whereas the large molecular template is used to create mesopores [11].

The formation of mesoporous zeolites gives lots of advantages in many applications especially in various catalytic reactions. They are primarily useful in improving the catalytic performances of conventional zeolites that having only micropores [12]. Some examples of catalytic reactions that used mesoporous zeolites are cracking, alkylation, isomerization and hydrogenation [13]. Knoevenagel condensation reaction is another example of catalytic reactions being catalyzed by mesoporous zeolites (alkaline X and Y zeolites) [14]. This reaction involved the condensation of carbonyl compounds with active methylene and catalyzed by a base catalyst. Some important intermediates produced from Knoevenagel condensation reactions have significant applications in industries such as therapeutic drugs, perfumes and cosmetics [15].

In this work, we focused on the synthesis of mesoporous sodalite (SOD). SOD is an example of zeolite, consisting of a four membered ring with the smallest pore openings size of about $2.8 \AA$ in the zeolite family. In addition, SOD is an example of basic zeolite with high aluminium content $(\mathrm{Si} / \mathrm{Al}=1)$ and high stability in basic solution [16]. However, the presence of ultrafine micropores in its structure limit only to the reaction involving small reactants. Therefore, this work is expected to solve the problem by synthesizing mesoporous SOD in order to catalyze Knoevenagel condensation reaction involving large reactants. This mesoporous SOD was synthesized by dual templates approach using different quaternary ammonium cation templates and mixed with tetrapropylammonium hydroxide (TPAOH). The catalyst activity was tested in the Knoevenagel condensation reaction of benzaldehyde with diethyl malonate.

\section{Catalyst preparation}

\section{Materials and Methods}

A series of SOD samples were prepared by following the molar ratio of the previous study; $1.7 \mathrm{SiO} 2: 15 \mathrm{NaOH}_{2}$ $\mathrm{Al}_{2} \mathrm{O}: 80 \mathrm{H}_{2} \mathrm{O}: 0.3$ templates [17]. First, sodium hydroxide solution was prepared by dissolving $\mathrm{NaOH}$ pellets $(\mathrm{NaOH}$; Merck; $15 \mathrm{~g})$ in distilled water $(18 \mathrm{~mL})$. The $\mathrm{NaOH}$ solution was then divided into two portions equally. 
One portion of the $\mathrm{NaOH}$ solution was mixed with fume silica $\left(\mathrm{SiO}_{2}\right.$; Fluka; $\left.1.28 \mathrm{~g}\right)$ to form silicate solution. The other portion was mixed with sodium aluminate $\left(\mathrm{NaAlO}_{2}\right.$; Riedel-de Haë; $\left.1.28 \mathrm{~g}\right)$ to form aluminate solution. Next, tetrapropylammonium hydroxide (TPAOH; Merck; $0.85 \mathrm{~mL})$ was added into the silicate solution followed by dimethyloctadecyl[3-(trimethoxysilyl)propyl] ammonium chloride (Organosilane; Sigma-Aldrich; $2.09 \mathrm{~mL}$ ). The mixture was stirred until clear solution was formed. The resulting solution was then added dropwise into the aluminate solution and stirred of about 1 hour. The resulting solution formed was transferred into stainless steel autoclave and heated at $150{ }^{\circ} \mathrm{C}$ for 24 hours for the precipitation of SOD. The SOD product was collected by filtration and washed using distilled water until the filtrate solution reached to $\mathrm{pH}$ 7. The product was then dried at $60{ }^{\circ} \mathrm{C}$ overnight and calcined at $550{ }^{\circ} \mathrm{C}$ for 6 hours.

The procedures were repeated for different mixture of templates: the mixture of TPAOH with cetyltrimethylammonium bromide (CTAB; Fisher Scientific), dodecyltrimethylammonium bromide (DTAB; SigmaAldrich) and dimethyldioctadecylammonium bromide (DDAB; Sigma-Aldrich). As comparison, microporous SOD (Na-SOD) was synthesized using the same method without the presence of templates.

\section{Characterizations}

X-ray diffraction (XRD) patterns were recorded on powder diffractometer (Bruker Advance D8, $40 \mathrm{kV}, 10 \mathrm{~mA}$ ) using a $\mathrm{Cu}-\mathrm{K} \alpha$ radiation source in the range of $5-50^{\circ}$. The FTIR analysis was recorded in the range of 400 to 4000 $\mathrm{cm}^{-1}$ using Perkin Elmer 1600 series spectrometer. The BET analysis of the samples was determined by $\mathrm{N}_{2}$ adsorption-desorption isotherms using a Micromeritics ASAP 2010 instrument. The samples were outgassed at $90{ }^{\circ} \mathrm{C}$ for 1 hour and heated up again at $350{ }^{\circ} \mathrm{C}$ for 4 hours before being subjected to $\mathrm{N}_{2}$ adsorption. The surface area measurement was derived from the Brunauer - Emmett - Teller (BET) theory and the pore size distributions based on Barrett, Joyner and Halenda (BJH) theory.

\section{Basicity measurements}

Basicity of all SOD samples was determined using Hammett indicators and back titration method. In the case of the former, the procedure was followed from previous study with some modifications [18]. An activated solid SOD sample was shaken with $2 \mathrm{~mL}$ solution of Hammett indicators in ethanol and left to equilibrate. The color changed was noted. The following Hammett indicators were used; bromothymol blue $\left(p \mathrm{~K}_{\mathrm{a}}=7.2\right)$, phenolphthalein $\left(p \mathrm{~K}_{\mathrm{a}}=\right.$ 8.2) and 4-nitroaniline ( $\left.p \mathrm{~K}_{\mathrm{a}}=18.4\right)$.

In the back titration method, an amount of activated solid SOD sample was suspended in $10 \mathrm{~mL}$ of distilled water. It was shaken and left for 1 day. After one day, the solution was filtered. Then, the filtrate was mixed with $5 \mathrm{~mL}$ of $0.05 \mathrm{M} \mathrm{HCl}$ (Qrëc). The resulting solution was next titrated against $0.02 \mathrm{M}$ of $\mathrm{KOH}$ (Qrëc) using phenolphthalein as the indicator. End point was noted when the colorless color of the phenolphthalein changed to pink.

Basicity comparison between Na-SOD sample and mesoporous SOD with highest BET surface area was done by Temperature Program Desorption of $\mathrm{CO}_{2}\left(\mathrm{TPD}-\mathrm{CO}_{2}\right)$ using AutoChem II 2920 Micromeritics Chemisorption analyzer. Sample was heated in a stream of $\mathrm{He}$ gas at the flow rate of $20 \mathrm{~mL} / \mathrm{min}$ to $500{ }^{\circ} \mathrm{C}$ at the heating rate of $10{ }^{\circ} \mathrm{C} / \mathrm{min}$ for 2 hours and then cooled to $50{ }^{\circ} \mathrm{C}$. After cooling, the $\mathrm{CO}_{2}$ gas was introduced at the rate of $20 \mathrm{~mL} / \mathrm{min}$ for 30 minutes. After that the gas flow was changed to $\mathrm{He}$ as carrier gas. The TPD- $\mathrm{CO}_{2}$ was carried out in the temperature range of 50 to $1000{ }^{\circ} \mathrm{C}$ at heating rate of $10{ }^{\circ} \mathrm{C} / \mathrm{mL}$ and $\mathrm{He}$ rate of $20 \mathrm{~mL} / \mathrm{min}$.

\section{Catalytic testing}

Knoevenagel condensation reaction of benzaldehyde and diethyl malonate was carried out in this study. The catalyst samples were first activated at $500{ }^{\circ} \mathrm{C}$ for 2 hours. Equimolar solutions of benzaldehyde $(0.02 \mathrm{~mol})$ and diethyl malonate $(0.02 \mathrm{~mol})$ were added into a $50 \mathrm{~mL}$ round bottom glass reactor. The $0.05 \mathrm{~g}$ catalyst powder was then added to the solution. $\mathrm{N}_{2}$ gas was then bubbled through the solution to remove dissolved oxygen to avoid formation of benzoic acid. Lastly, the solution was connected to the condenser and refluxed in an oil bath at $150{ }^{\circ} \mathrm{C}$ for 24 hours with stirring. Products of reaction were separated and analyzed using Gas Chromatography model Agilent $6890 \mathrm{~N}$ Series equipped with flame ion detector (FID) using Ultra-1 column. Meanwhile, the components of the product produced in the reaction were identified by using Gas Chromatography-Mass Spectroscopy (GC-MS) model Perkin Elmer Clarus 680. 


\section{Catalyst characterizations}

\section{Results and Discussion}

Figure 1 shows the XRD patterns of the as-synthesized SOD samples. The patterns exhibited six diffraction peaks at $2 \theta=14.10^{\circ}, 24.40^{\circ}, 31.60^{\circ}, 34.70^{\circ}, 37.60^{\circ}$ and $48.80^{\circ}$ correspond to $d_{[110]}, d_{[211]}, d_{[310]}, d_{[222]}, d_{[321]}$ and $d_{[330]}$ planes respectively. These patterns are assigned to SOD crystal phase pattern after comparing with the previous study [19]. Among the SOD samples, SOD-TO showed broader XRD peaks which indicated a smallest crystallite size in its structure. In some cases, mixture of phases could be seen for SOD. It can be observed that the XRD pattern for SOD-TDDAB sample produced two peaks at certain $2 \theta$. However, the extra peaks could not be identified and not matched with other type of zeolites. As for other SOD samples, peaks with high intensity were observed. The diffraction peak at (211) corresponding to the most intense peak was selected to calculate the crystallite size using Debye-Scherrer equation. The results correspond to the crystallite size of all SOD samples are shown in Table 1. The values suggested that all SOD samples were composed of nano-sized crystals. In addition, the values also suggested that the crystallite size increases as the wideness of the diffraction peak decreases. The SOD-TO sample has the smallest crystallite size as compared with other SOD samples which indicated that this sample consists of a highly nanocrystalline nature of the framework due to the presence of small crystallite size.

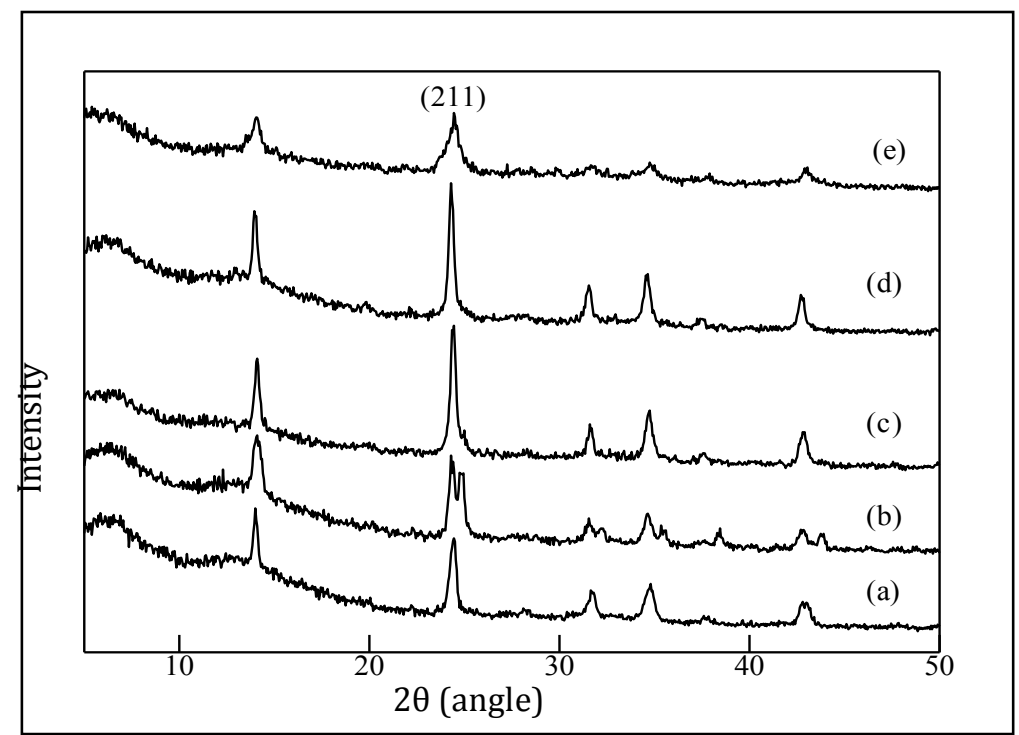

Figure 1. XRD diffractograms of (a) Na-SOD, (b) SOD-TDDAB, (c) SOD-TCTAB, (d) SOD-TDTAB and (e) SOD-TO

Table 1. Crystallite size of all SOD samples

\begin{tabular}{lc}
\hline Samples & Crystallite size (nm) \\
\hline Na-SOD & 18 \\
SOD-TDDAB & 23 \\
SOD-TCTAB & 25 \\
SOD-TDTAB & 26 \\
SOD-TO & 17 \\
\hline
\end{tabular}

Figure 2 shows the IR spectra of as-synthesized SOD samples. Each SOD sample showed a broad absorption band at around $980 \mathrm{~cm}^{-1}$. This band can be assigned to the internal vibration of T-O-T ( $\mathrm{T}=\mathrm{Si}$ or $\left.\mathrm{Al}\right)$ asymmetric stretch. 
However, except SOD-TO sample, all other SOD samples showed additional absorption band at around $920 \mathrm{~cm}^{-1}$. This band could be assigned to the $\mathrm{Si}-\mathrm{O}$ stretching mode of surficial silanol group (Si-OH). This band might be produced due to the hydroxylation of silica upon exposure to water. In addition, each of SOD samples showed absorption bands in the region of $650-740 \mathrm{~cm}^{-1}$ that can be due to the symmetric stretch of T-O-T $(\mathrm{T}=\mathrm{Si}$ or $\mathrm{Al})$. While, the absorption band around $450-465 \mathrm{~cm}^{-1}$ represents the internal vibration of T-O-T bending $(\mathrm{T}=\mathrm{Si}$ or $\mathrm{Al})$. The characteristic absorption band at $428-436 \mathrm{~cm}^{-1}$ also represent the vibrations of T-O-T $(\mathrm{T}=\mathrm{Si}$ or $\mathrm{Al})$ bending that related to the pore opening of the SOD unit. The absorption bands discussed are related to the characteristic of SOD framework as found by previous study [20].

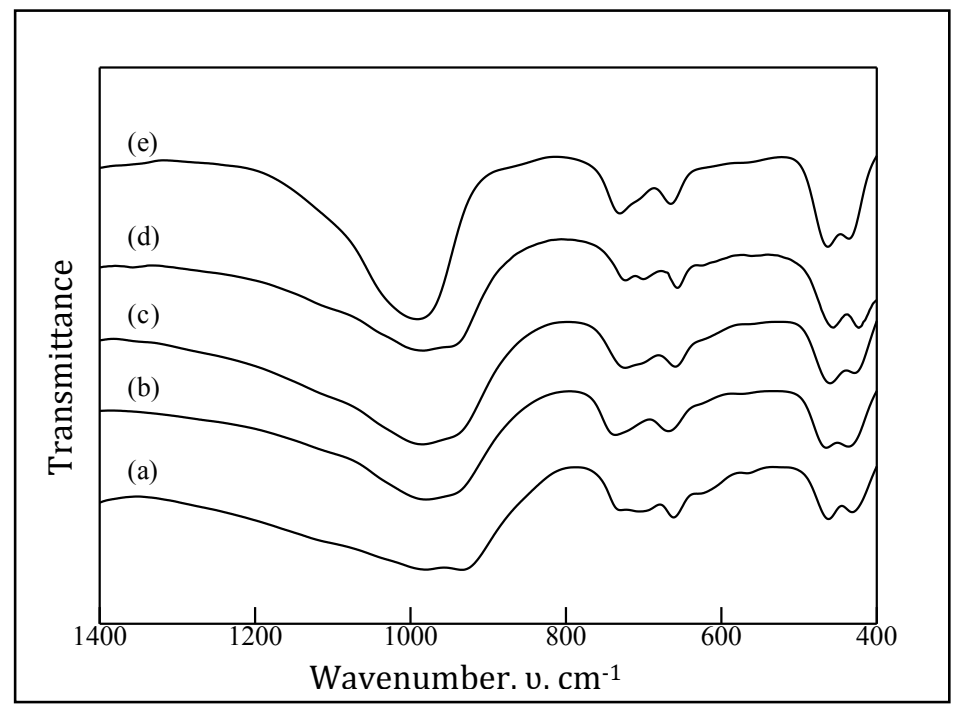

Figure 2. IR spectra of (a) Na-SOD, (b) SOD-TDDAB, (c) SOD-TCTAB, (d) SOD-TDTAB and (e) SOD-TO

Figure 3 shows the BET adsorption-desorption isotherm of all SOD samples while Figure 3B shows the BJH pore size distributions of all SOD samples. Based on Figure 3A, the BET adsorption-desorption isotherm of the SOD-TO sample (see Figure 3 (e)) exhibited type IV isotherm with a H1 type hysteresis loop which was typical of mesoporous solids. This hysteresis loop produced was due to the capillary condensation in mesopore channels. As for other SOD samples, the isotherms can be classified as type II isotherm with a non-uniform type H3 hysteresis loop. While, the Na-SOD sample produced type II isotherm with type H2 hysteresis loop. Thus, only SOD-TO sample showed the successfully formation of mesoporosity in its structure based on the obtained isotherm. The presence of mesoporous structure in the SOD-TO sample was confirmed with a narrow pore size distribution peak centered at $c a$. $66 \AA$ as shown in Figure 4 (e). In addition, the higher specific surface area and larger pore volume were attributed to the presence of mesoporous structure in the SOD-TO as shown in Table 2. As for other SOD samples, they exhibited broader pore size distributions ranging from $30 \AA$ to $475 \AA$ and some even extended to the macropore range. This suggested that those samples inhibited the characteristic of an ordered mesoporous solid with very low BET surface area as shown in Table 2. 


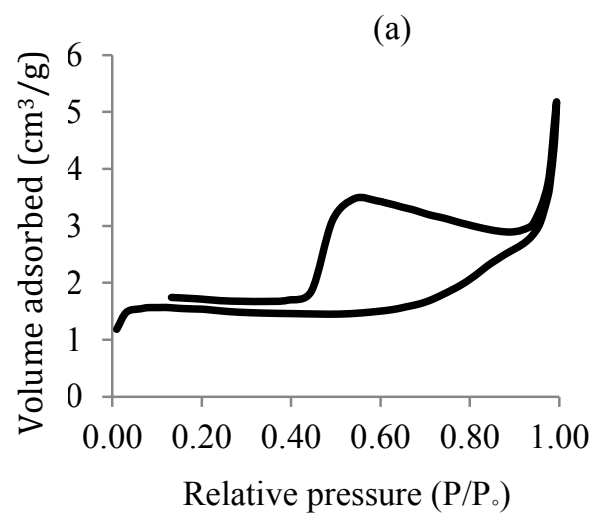

(c)

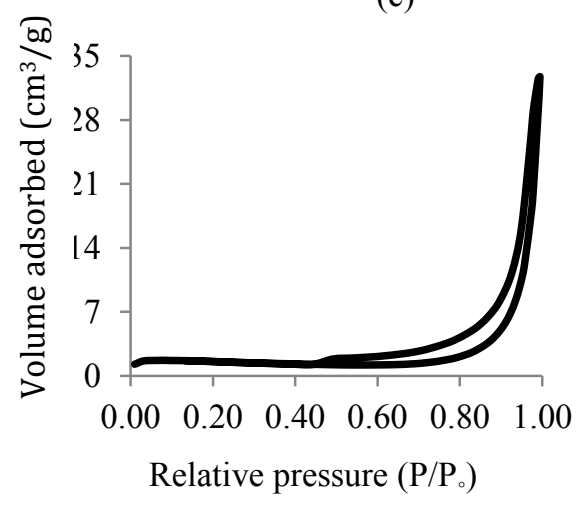

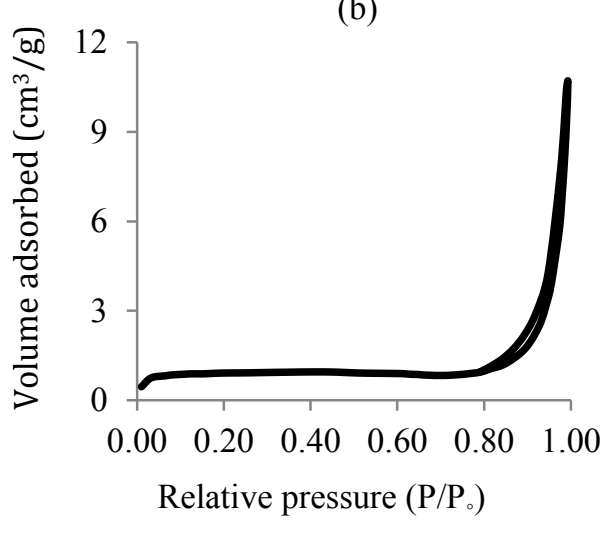

(d)

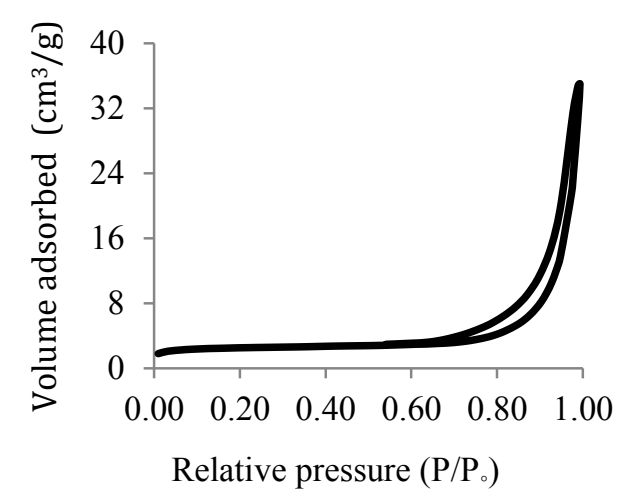

(e)

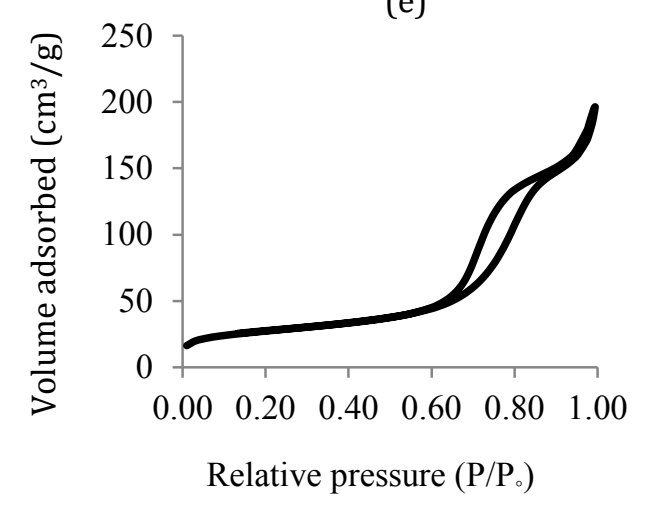

Figure 3. BET adsorption-desorption isotherm of (a) Na-SOD, (b) SOD-TDDAB, (c) SOD-TCTAB, (d) SODTDTAB and (e) SOD-TO 
Table 2. $\mathrm{N}_{2}$ adsorption-desorption data of all SOD samples

\begin{tabular}{|c|c|c|c|c|}
\hline Samples & $\begin{array}{c}\text { BET Surface } \\
\text { Area, } \mathbf{S}_{\text {BET }} \\
\left(\mathrm{m}^{2} / \mathrm{g}\right) \\
\end{array}$ & $\begin{array}{c}\text { t-plot } \\
\begin{array}{c}\text { Micropore Area } \\
\left(\mathbf{m}^{2} / \mathbf{g}\right)\end{array} \\
\end{array}$ & $\begin{array}{c}\text { External } \\
\text { Surface Area, } \\
\mathbf{S}_{\text {Ext }}\left(\mathbf{m}^{2} / \mathbf{g}\right) \\
\end{array}$ & $\begin{array}{c}\text { BJH Desorption } \\
\text { Cumulative Volume } \\
\text { of Pores }\left(\mathrm{cm}^{3} / \mathrm{g}\right)\end{array}$ \\
\hline $\mathrm{Na}-\mathrm{SOD}$ & 6.8 & 6.0 & 0.8 & 0.007 \\
\hline SOD-TDDAB & 3.3 & 2.4 & 0.9 & 0.012 \\
\hline SOD-TCTAB & 6.8 & 5.8 & 0.9 & 0.051 \\
\hline SOD-TDTAB & 9.1 & 6.6 & 2.5 & 0.049 \\
\hline SOD-TO & 94.2 & 19.2 & 75.0 & 0.285 \\
\hline
\end{tabular}

(a)

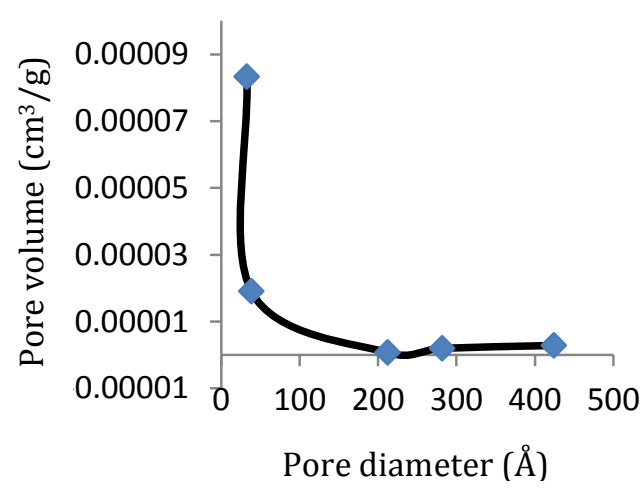

(c)

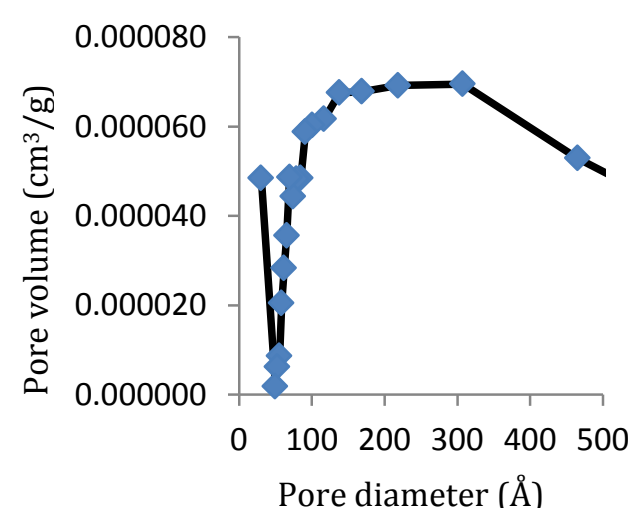

(b)

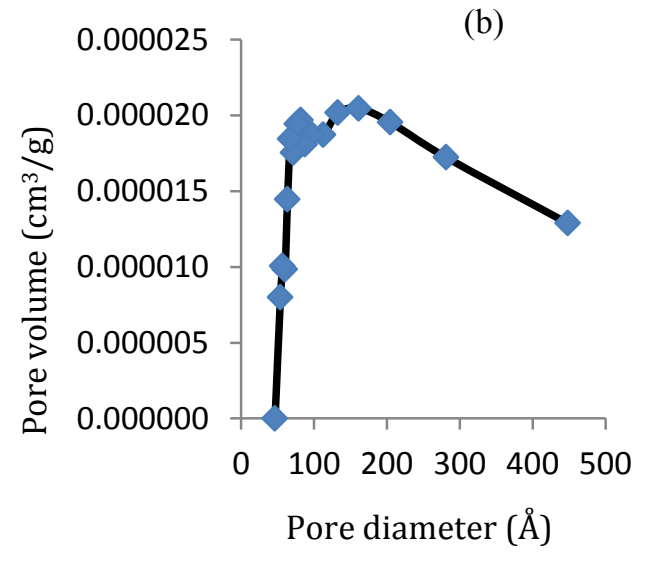

(d)

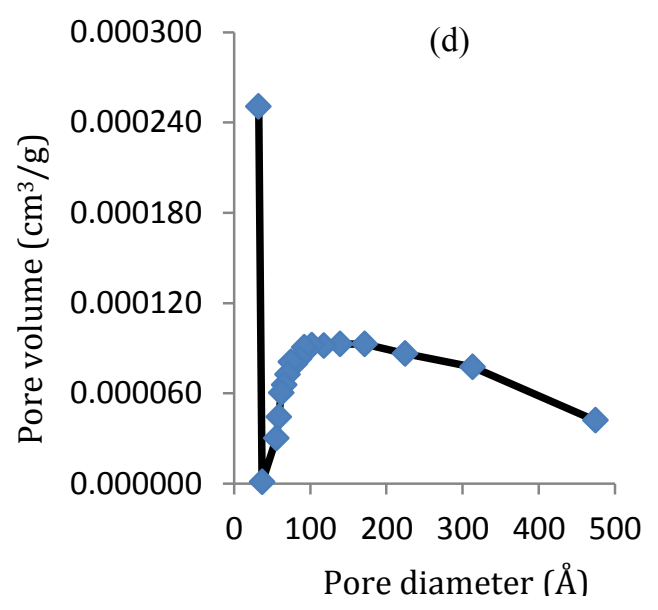


(e)

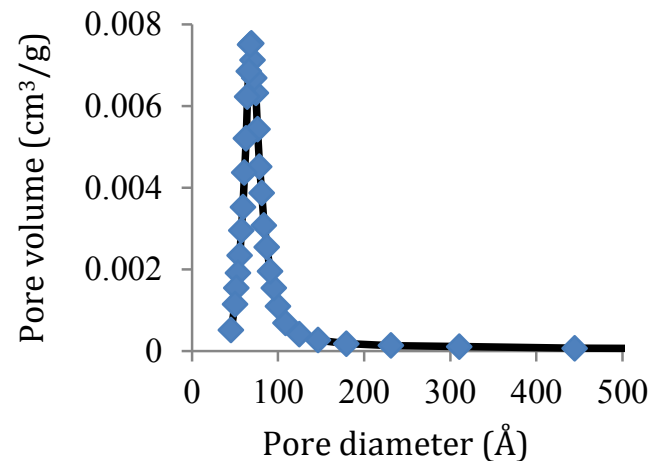

Figure 4. BJH pore size distributions of (a) Na-SOD, (b) SOD-TDDAB, (c) SOD-TCTAB, (d) SOD-TDTAB and (e) SOD-TO

\section{Basicity measurements}

The basic strength of the SOD samples was estimated by using Hammett indicators. A change in color was observed for bromothymol blue from orange to dark blue and colorless to pink for phenolphthalein indicators. None of the samples were able to change the color of 4-nitroaniline. Hence, the strength of the basicity of all SOD samples prepared in this study was estimated in the range: $8.2 \leq \mathrm{pKa} \leq 18.4$ as shown in Table 3 .

Table 3. Basic strength of all SOD samples

\begin{tabular}{lcccc}
\hline \multirow{2}{*}{ Samples } & \multicolumn{3}{c}{ Hammett Indicators } & Basic Strength \\
\cline { 2 - 5 } & Bromothymol Blue & Phenolphthalein & 4-nitroaniline & \\
\hline Na-SOD & ${ }^{*}$ & + & $-{ }^{*}$ & $8.2 \leq \mathrm{pKa} \leq 18.4$ \\
SOD-TDDAB & + & + & - & $8.2 \leq \mathrm{pKa} \leq 18.4$ \\
SOD-TCTAB & + & + & - & $8.2 \leq \mathrm{pKa} \leq 18.4$ \\
SOD-TDTAB & + & + & - & $8.2 \leq \mathrm{pKa} \leq 18.4$ \\
SOD-TO & + & + & - & $8.2 \leq \mathrm{pKa} \leq 18.4$ \\
\hline
\end{tabular}

$*(+)=$ color changed,$(-)=$ color unchanged

The similar strength of all the samples suggested that the basicity strength is contributed by the type of counter cation used and not the porosity. In this study, similar alkali cation which was $\mathrm{Na}^{+}$was used as the counter cation during the synthesis of all sodalite samples.

The amount of basicity of the SOD samples was evaluated by back titration method. Results found that the average amount of basicity of all SOD samples synthesized with the presence of templates is more than two fold higher than the SOD synthesized without the presence of templates, Na-SOD as shown in Table 4. Among the SOD samples synthesized with the presence of templates, it was found that the SOD-TO sample possess the highest average amount of basicity as compared with other SOD samples. This result indicated that the highest basic sites were present in the SOD-TO sample and lead to the highest amount of basicity. This could be due to the mesopore structure present in the sample, which more accessible of the reactant for the basic sites. 
Table 4. Average amount of basicity of all SOD samples

\begin{tabular}{lcccc}
\hline Sample & \multicolumn{3}{c}{$\begin{array}{c}\text { Amount of Basicity } \\
\text { (mmol/g) }\end{array}$} & $\begin{array}{c}\text { Average Amount of Basicity } \\
\text { (mmol/g) }\end{array}$ \\
\cline { 2 - 4 } & (i) & (ii) & (iii) & \\
\hline Na-SOD & 0.60 & 0.80 & 0.80 & 0.73 \\
SOD-TDDAB & 1.72 & 1.76 & 1.76 & 1.75 \\
SOD-TCTAB & 1.64 & 1.68 & 1.68 & 1.67 \\
SOD-TDTAB & 1.68 & 1.72 & 1.72 & 1.71 \\
SOD-TO & 1.80 & 1.80 & 1.84 & 1.81 \\
\hline
\end{tabular}

Comparison of the strength and the amount of basicity for mesoporous SOD-TO and microporous Na-SOD samples were measured using TPD- $\mathrm{CO}_{2}$ analysis. The basicity profiles of SOD-TO and Na-SOD samples are presented in Figure 5. Four peaks were found for the SOD-TO sample which centred at 131.7, 210.4, 688.8 and $895.4{ }^{\circ} \mathrm{C}$ with the amount of $\mathrm{CO}_{2}$ desorbed of $0.1098,1.0632,0.2789$ and $0.4242 \mathrm{mmol} / \mathrm{g}$, respectively. Meanwhile, three peaks were observed for the Na-SOD sample which centred at 142.0, 723.5 and $875.5{ }^{\circ} \mathrm{C}$ with the amount of $\mathrm{CO}_{2}$ desorbed of $0.0867,0.4278$ and $0.2946 \mathrm{mmol} / \mathrm{g}$, respectively.

Since the activation temperature of the catalyst for the catalytic study was carried out at $500{ }^{\circ} \mathrm{C}$, thus the amount of $\mathrm{CO}_{2}$ desorbed was compared in the range of temperature below $500{ }^{\circ} \mathrm{C}$. It was observed that at temperature below $500{ }^{\circ} \mathrm{C}$, the amount of $\mathrm{CO}_{2}$ desorbed for the SOD-TO sample was higher than that of the Na-SOD sample. In this study, the peaks with broader width and high peak area for the SOD-TO sample was found at around $300{ }^{\circ} \mathrm{C}$. This suggested that within this range of temperature, more $\mathrm{CO}_{2}$ was desorbed from SOD-TO sample. From the results, at temperature below $500{ }^{\circ} \mathrm{C}$, the amount of basic site for the SOD-TO sample is higher than the Na-SOD sample. This phenomenon should be due to the presence of mesoporosity in the SOD-TO sample that leads to the increase in the basic sites available for $\mathrm{CO}_{2}$ to react. Thus, more $\mathrm{CO}_{2}$ is physically attached within the mesopores channels of the SOD-TO sample. It is also suggested that the interaction of $\mathrm{CO}_{2}$ with the basic site in the mesopore channels is not very strong and can be easily detached at lower temperature

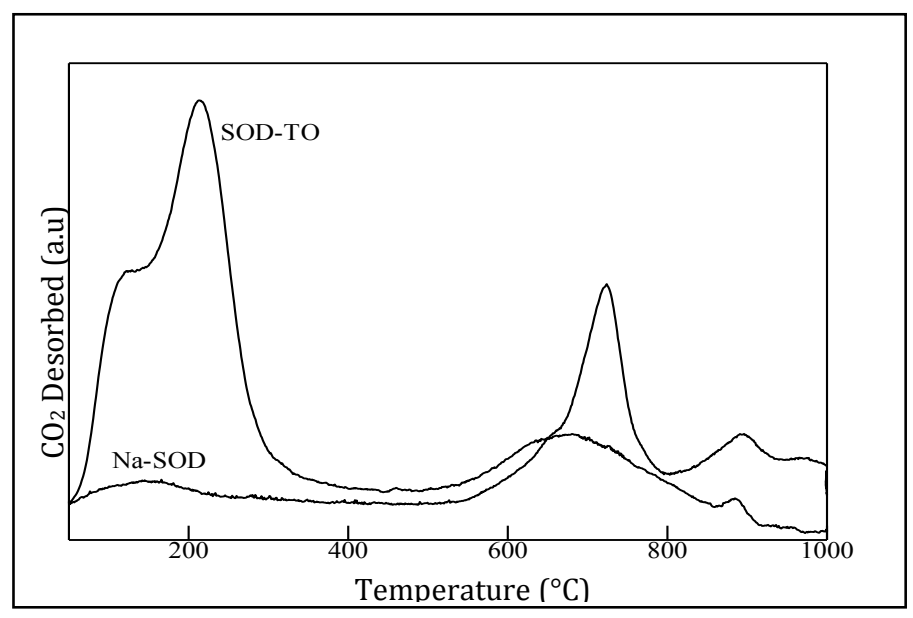

Figure 5. TPD- $\mathrm{CO}_{2}$ analysis for the SOD-TO and Na-SOD samples 


\section{Catalytic activity study}

The catalytic activity of all SOD samples was tested as base catalysts in the reaction Knoevenagel condensation reaction between benzaldehyde and diethyl malonate. The reaction was expected to give an enone which was diethyl-2-benzylidenemalonate as the major product as shown in Scheme 1.

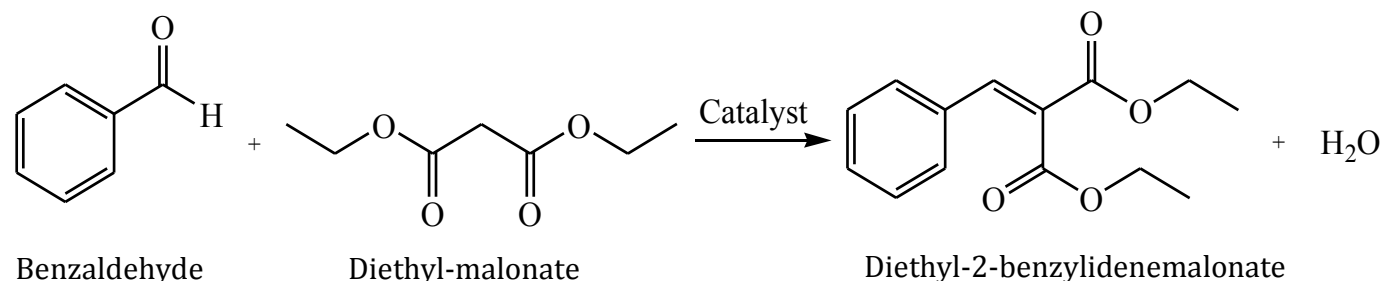

Scheme 1. Equation of Knoevenagel condensation reaction between benzaldehyde and diethyl malonate

Since the results of the reaction showed that the reactants were converted into products, it was suggested that all SOD catalysts synthesized in this study were active for the Knoevenagel condensation reaction. As shown in Scheme 1, it was deduced that only one product produced from the reaction. However, two side products were obtained from this reaction. The most probable compounds produced as side products belong to ethyl cinnamate as a major side product and diethyl 2, 2- bis(hydroxy(phenyl)methyl) malonate as a minor side product. The reactivity of the SOD catalysts was studied in term of percentages of conversion and selectivity. Besides, the percentage of yield for all SOD catalysts was calculated based on the major product. The percentages of yield, conversion and selectivity of the SOD catalysts are listed in Table 5. SOD-TO produce the highest percentage of conversion $(96.29 \%)$ followed by SOD-TDDAB (95.84\%), Na-SOD (95.63\%), SOD-TDTAB (42.02\%) and SOD-TCTAB $(13.25 \%)$ after 24 hours reaction. The higher percentage conversation of SOD-TO could be due to the higher possibility of reactants to access to the active basic sites present in their mesopores. In addition, the SOD-TO catalyst possessed the higher amount of basicity indicated the higher amount of the active basic sites is available. From Table 5, the SOD-TO catalyst showed the highest percentage of yield for the major product as compared with other SOD catalysts which was $34.80 \%$.

Table 5. Percentages of conversion, selectivity and yield of all SOD catalysts

\begin{tabular}{|c|c|c|c|c|c|}
\hline \multirow{2}{*}{ Sample } & \multirow{2}{*}{ Conversion (\%) } & \multicolumn{3}{|c|}{ Selectivity (\%) } & \multirow{2}{*}{ Yield (\%) } \\
\hline & & $\begin{array}{c}\text { Major } \\
\text { Product }\end{array}$ & $\begin{array}{c}\text { Major Side } \\
\text { Product }\end{array}$ & $\begin{array}{c}\text { Minor Side } \\
\text { Product }\end{array}$ & \\
\hline Na-SOD & 95.63 & 18.66 & 61.05 & 20.29 & 17.84 \\
\hline SOD-TDDAB & 95.84 & 22.88 & 68.11 & 9.01 & 21.93 \\
\hline SOD-TCTAB & 13.25 & 72.30 & 0.91 & 26.79 & 9.58 \\
\hline SOD-TDTAB & 42.02 & 59.83 & 3.15 & 37.02 & 25.14 \\
\hline SOD-TO & 96.29 & 36.14 & 45.66 & 18.20 & 34.80 \\
\hline
\end{tabular}

\section{Conclusion}

Mesoporous sodalite (SOD-TO) was successfully synthesized in the presence of tetrapropylammonium hydroxide $(\mathrm{TPAOH})$ and organosilane templates using molar oxide ratio of $1.7 \mathrm{SiO}_{2}: 15 \mathrm{NaOH}: \mathrm{Al}_{2} \mathrm{O}_{3}: 80 \mathrm{H}_{2} \mathrm{O}: 0.3$ templates. On the other hand, the rest of sodalite samples synthesized using TPAOH mixed with quaternary ammoniums other than organosilane, only produced microporous sodalite. All the as-synthesized samples showed the XRD patterns of sodalite phase indicating the successful formation of sodalite phase crystal. While, FTIR results revealed that all absorption patterns shown by all the as-synthesized samples are related to the characteristic of sodalite framework. From $\mathrm{N}_{2}$ adsorption analysis, SOD-TO showed the successful formation of mesoporosity contains mesoporousmicroporous hierarchical structure with the highest BET surface area. All the as-synthesized sodalite samples 
showed the basicity strength in the range: $8.2 \leq \mathrm{pKa} \leq 18.4$ with mesoporous SOD-TO sample showed the highest amount of basicity. TPD- $\mathrm{CO}_{2}$ analysis found that the mesoporous SOD-TO sample gave higher strength and amount of basic sites than the Na-SOD sample at temperature below $500^{\circ} \mathrm{C}$. The SOD-TO catalyst with the highest amount of basicity and the highest surface area is most active, giving the highest percentages of conversion and yield in the Knoevenagel condensation reaction of benzaldehyde and diethyl malonate.

\section{Acknowledgements}

Authors would like to thank Universiti Teknologi Malaysia (UTM) and Ministry of Higher Education (MOHE) for financial assistant under GUP Vot No QJ13000.2526.06H70.

\section{References}

1. Weckhuysen, B. M. and Yu, J. (2015). Recent advances in zeolite chemistry and catalysis. Chemical Society Reviews, 44 (20): 7022 - 7024.

2. Arya, K. and Tomar, R. (2015). Microporous zeolite catalyst system: An eco-approach for regioselective synthesis of pyrimidobenzimidazoles. Research on Chemical Intermediates, 41(6): $3389-3400$.

3. Zhao, J., Wang, G., Qin, L., Li, H., Chen, Y. and Liu, B. (2016). Synthesis and catalytic cracking performance of mesoporous zeolite Y. Catalysis Communications, 73: 98 - 102.

4. Mukti, R. R., Kamimura, Y. and Chaikittisilp, W. (2011). Hierarchically porous ZSM-5 synthesized by nonionic- and cationic-templating routes and their catalytic activity in liquid-phase esterification. ITB Journal of Science, 43 (1): $59-72$.

5. Zhu, J., Meng, X. and Xiao, F. (2013). Mesoporous zeolites as efficient catalysts for oil refining and natural gas conversion. Frontiers of Chemical Science and Engineering, 7(2): 233 - 248

6. Wei, Y., Parmentier, T. E., de Jong, K. P. and Zecevic, J. (2015). Tailoring and visualizing the pore architecture of hierarchical zeolites. Chemical Society Reviews, 44(20): $7234-7261$.

7. Vernimmen, J., Meynen, V. and Cool, P. (2011). Synthesis and catalytic applications of combined zeolitic/mesoporous materials. Beilstein Journal of Nanotechnology, 2: 785 - 801.

8. Moliner, M. (2012). Direct synthesis of functional zeolitic materials. ISRN Materials Science, 2012: 1 -24.

9. Chen, Z., Zhang, J. and Yu, B. (2015). Amino acid mediated mesopore formation in LTA zeolites. Journal of Materials Chemistry A, 4(6): 2305 - 2313.

10. Jiao, W. Q., Fu, W. H. and Liang, X. M. (2014). Preparation of hierarchically structured Y zeolite with low $\mathrm{Si} / \mathrm{Al}$ ratio and Its applications in acetalization reactions. RSC Advances, 4(102): $58596-58607$.

11. Emdadi, L., Wu, Y., Zhu, G., Chang, C. C., Fan, W., Pham, T. and Liu, D. (2014). Dual template synthesis of meso- and microporous MFI zeolite nanosheet assemblies with tailored activity in catalytic reactions. Chemistry of Materials, 26(3): $1345-1355$.

12. Na, K. and Somorjai, G. A. (2014). Hierarchically nanoporous zeolites and their heterogeneous catalysis: Current status and future perspectives. Catalysis Letters, 145(1): $193-213$.

13. Jie, Z., X. M. and Fengshou, X. (2013). Mesoporous zeolites as efficient catalysts for oil refining and natural gas conversion. Frontiers of Chemical Science and Engineering, 7(2): 233 - 248.

14. Corma, A., Fornés, V. and Martín-Aranda, R. M. (1990). Zeolites as base catalysts: Condensation of aldehydes with derivatives of malonic esters. Applied Catalysis, 59(1): $237-248$.

15. Muralidhar, L. and Girija, C. R. (2014). Simple and practical procedure for knoevenagel condensation under solvent-free conditions. Journal of Saudi Chemical Society, 18(5): 541 - 544.

16. Yao, J., Zhang, L., and Wang, H. (2008). Synthesis of nanocrystalline sodalite with organic additives. Materials Letters, 62(24), $4028-4030$.

17. Shanbhag, G. V., Choi, M., Kim, J. and Ryoo, R. (2009). Mesoporous sodalite: A novel, stable solid catalyst for base-catalyzed organic transformations. Journal of Catalysis, 264(1): 88 - 92.

18. Rahul, R., Satyarthi, J. K. and Srinivas, D. (2011). Lanthanum and zinc incorporated hydrotalcites as solid base catalysts for biodiesel and biolubricants production. Indian Journal of Chemistry-Section A, 50: 1017 - 1025.

19. Treacy, M. M. J. and Higgins J. B. (2001). Collection of simulated XRD powder patterns for zeolites. Elsevier, Amsterdam.

20. Yao, J., Wang, H., Ratinac, K. R., and Ringer, S. P. (2006). Formation of colloidal hydroxy-sodalite nanocrystals by the direct transformation of silicalite nanocrystals. Chemistry of Materials, 18(6): $1394-1396$. 